\title{
Dietary overlap of wild ungulate Cuvier's gazelle with livestock (sheep and goats) in Djebel Messaâd Forest, Algeria
}

\author{
Naceur Benamor*, Farid Bounaceur \& Stéphane Aulagnier
}

\begin{abstract}
Studying the dietary habits of wild animals is essential for the efficient wildlife management. This paper presents the results of dietary overlap of Cuvier's gazelle (Gazella cuvieri) and two species of livestock to evaluate whether or not they compete for forage. The study was conducted from September 2016 to August 2017 in the Djebel Messaâd Forest, Algeria, using microhistological analysis. The diet of Cuvier's gazelle and livestock maintained a high proportion of grasses, shrubs and trees. At Djebel Messaâd Forest, of the total 48 food plant species identified in fecal samples, 39 of which were found in Cuvier's gazelle, 29 and 36 from domestic sheep and goats respectively; 20 genera occurred in the annual diets of both Cuvier's gazelle and livestock. The principal foods were browses $(N \%=52.6)$ for Cuvier's gazelle, while the dominant forage species included Stipa tenacissima, Artemisia herba alba, Pistacia terebinthus, Stipa parviflora, Helianthemum sp. The food diversity was invariably high for Cuvier's gazelle in autumn and generally decreased from winter to summer, we conclude that this gazelle exhibited a higher dietary diversity than livestock. Shared species 21 represented a higher proportion of dietary items for Cuvier's gazelle $(N \%=76.9)$ than for sheep $(N \%=54.0)$. While shared 28 species, a very higher proportion of those used by Cuvier's gazelle $(N \%=91.4)$ than by goats $(N \%=61.2)$. Dietary overlap indices confirmed that, livestock had very similar diets. while, both of them had moderate diet overlap with Cuvier's gazelle.
\end{abstract}

How to cite this article: Benamor N., Bounaceur F., Aulagnier S. 2021. Dietary overlap of wild ungulate Cuvier's gazelle with livestock (sheep and goats) in Djebel Messaâd Forest, Algeria // Russian J. Theriol. Vol.20. No.1. P.31-43. doi: 10.15298/rusjtheriol.20.1.05.

KEY WORDS: diet overlap, Gazella cuvieri, livestock, faecal analysis, feeding ecology.

Naceur Benamor [naceur_mh28@yahoo.fr], Conservation Biologyin Arid and Semi-arid Areas, Department of Biology, Faculty of Natural Sciences and Life, Ibn Khaldoun University, Tiaret, Algeria; Farid Bounaceur [fbounaceur@yahoo. fr], Department of Biology, Faculty of Natural Sciences and Life, Ahmed Ben Yahia Al-Wancharissi University Center, Tissemsilt, Algeria; Stéphane Aulagnier [stephane.aulagnier@inra.fr], Behavior and Ecology of Wildlife, National Institute for Agricultural Research, Toulouse University, Castanet-Tolosan cedex, France.

\section{О перекрывании рационов питания диких копытных, газели Кювье и домашнего скота (овцы и козы) в лесу Джебель Мессаад, Алжир}

\author{
Н. Бенамор*, Ф. Бунасёр, С. Оланье
}

РЕЗЮМЕ. Исследование пищевых предпочтений диких животных необходимо для их эффективного менеджмента в природе. В этой работе представлены результаты исследования перекрывания рационов питания газели Кювье (Gazella cuvieri) и двух видов домашнего скота с целью оценки, являются ли они конкурентами за пищевые ресурсы. В работе, проводимой с сентября 2016 г. по август 2017 г. в лесу Джебель Мессаад, Алжир, был использован микрогистологический анализ. Пищевой рацион газели Кювье и домашнего скота в основном состоит из трав, кустарников и древесной растительности. В лесу Джебель Мессаад в помёте копытных было идентифицировано 48 видов кормовых растений, из них 39 было обнаружено у газели Кювье, 29 у домашних овец и 36 у домашних коз; представители 20 родов растений были встречены как у газелей, так и у домашнего скота. Основным кормом для газели Кювье являлись молодые побеги $(N \%=52.6)$, тогда как в видовом отношении основу рациона составляли Stipa tenacissima, Artemisia herba alba, Pistacia terebinthus, Stipa parviflora, Helianthemum sp. Разнообразие рациона для газели Кювье оставалось стабильно высоким в течение осени и в целом снижалось с зимы до лета, на основании чего мы приходим к выводу, что газели демонстрируют большее разнообразие в питании, чем домашний скот. Доля совместно употребляемых видов (21) составляет в рационе газелей Кювье большую пропорцию $(N \%=76.9)$ чем у овец $(N \%=54.0)$.

* Corresponding author 
В то же время доля совместно употребляемых видов $(28)$ между газелями $(N \%=91.4)$ и козами $(N \%=$ 61.2) ещё больше. Индекс пищевого перекрывания подтверждает, что виды домашнего скота имеют очень схожие диеты, в то время как оба этих вида в умеренной степени перекрываются по рациону с газелью Кювье.

КЛЮЧЕВЫЕ СЛОВА: перекрывание рационов, Gazella cuvieri, домашний скот, анализ экскрементов, экология питания.

\section{Introduction}

An organism's diet is a fundamental aspect of its ecological niche. Quantifying diets has long been and continues to be one of the first steps in studying a species' basic ecology (Sih \& Christensen, 2001). An understanding of the diet of a species is of fundamental importance for its management (Martinez, 2001), as well as a key factor in the conservation of a threatened species, and knowledge about it has several uses (Freschi et al., 2016). Information on food habits is an important component of an animal's life history and knowledge on diet selection is fundamental to understanding many aspects of ungulate ecology (Hobbs et al., 1983).

North Africa supports a diverse fauna. Livestock grazing is a common and traditional practice in this region (Papanastasis, 1997). Livestock grazing impacts on native wildlife are an important conservation concern globally (Prins, 1992; Fleischner, 1994; Voeten, 1999). The issue of competition between livestock and wild herbivores is contentious and a concern for both wildlife biologists and livestock operators (Vavra \& Sheehy, 1996; Mishra et al., 2004). Livestock herbivory may have either positive or negative impacts on ecosystem services, dependent both on the intensity of grazing, as well as on the prevailing local circumstances (Belsky \& Gelbard, 2000). Many studies on sympatric herbivores have been focused on spatio-temporal overlaps and on the effect of different grazing systems and stocking rates on wildlife habitats and forage quality, suggesting that exploitation competition was the central mechanism of interaction in wildlife-livestock systems (e.g., Coe et al., 2001; Stewart et al., 2002). Seligman \& Perevolotsky (1994) have found that vegetation in the Mediterranean basin is well adapted to intensive herbivory by domestic ungulates and low grazing pressure can have undesirable ecological and management consequences. With information on resource requirements, this may provide indirect evidence for the likelihood of one species affecting another (MacNally, 1983), although a high degree of overlap does not necessarily mean that competition is taking place (Wiens, 1977). Generally, high diet similarity between ungulate pairs indicates competitive interaction at high density and limited food resources. However, because species differ in morphological (Gordon \& Illius, 1988) and physiological (Hofmann, 1989) characteristics, which lead to different feeding styles (Hofmann \& Stewart, 1972).

The causes for differences in palatability among both grasses and other life forms are as not yet clearly understood in spite of the fact that numerous attempts had been made in the past to relate preference differences to a number of factors such as forage quality (Bailey, 1995; Van Dyne \& Heady, 1965; O'Reagain \& Mentis, 1989; Soder et al., 2009). Some fundamental differences exist between herbaceous forages consumed by herbivores, particularly between grasses (monocots) and browses (herbaceous and woody dicots such as forbs, shrub leaves and stems; Hofmann \& Stewart, 1972; Jarman, 1974). Hofmann (1989) classified grazers as species feeding almost exclusively on graminoids $(<25 \%$ browse). Browsers (or concentrate selectors) feed on at least $75 \%$ on woody and nonwoody dicotyledonous plants while mixed feeders feed on intermediate proportions of grass and browse.

The genus Gazella (Bovidae, Antilopinae) is distributed widely across Africa, the Middle East and Asia (Lerp et al., 2013). Cuvier's gazelle (Gazella cuvieri) is a mountain species endemic to North Africa, occupied the mountain ranges and hills of the Maghreb, and neighbouring ranges in Morocco, Algeria and Tunisia (Cuzin, 2003; Beudels et al., 2005). The species is currently globally threatened and is classified as "Vulnerable" in IUCN's Red List of Threatened Species, mainly due to its small population size (IUCN, 2016). In Algeria it occupies or occupied the slopes of the Tellian chains, those of the more southern massif formed by the Saharan Atlas, the flat regs between the Saharan Atlas and the Ergs, and the massifs in the eastern part of the country (de Smet, 1991). Most Algerian Cuvier's gazelles live in Aleppo pine forests (Pinus halapensis), with understory oaks (Quercus ilex, Q. coccifera) and Phylleria, with herbs such as Globularia and Rosmarinus and a grass, alfa (Stipa tenacissima), in open areas and in patches of regenerating forest (de Smet, 1991). Accurate population censuses are difficult in the forested areas of the range of Cuvier's gazelle (Moreno \& Espeso, 2008). Habitat degradation from overgrazing by livestock is also a concern (Kingdon, 1997; Beudels et al., 2005).

Although competition between livestock and wild herbivores has long been acknowledged to be an important (although contentious) issue (Mishra et al., 2004), recent reviews indicate a remarkable world-wide scarcity of studies addressing the issue (Kilonzo et al., 2005; La Morgia \& Bassano, 2009; Bhattacharya et al., 2012; Xu, 2012; Syed \& Khan, 2017). Knowledge of the feeding habits of wild animals is central to effective wildlife management and to many phases of ecological research in wild lands (Talbot \& Talbot, 1962). Bounaceur et al. (2016) pointed out that a more comprehensive investigation of the diet of the Cuvier's gazelle is urgently needed to identify critical habitats and 
suggest necessary conservation. Therefore, our work is a contribution in this direction. The annual diet overlap between Cuvier's gazelle and sympatric livestock has not been examined. Based on the assumption that goats are generally browsers, sheep consume mainly grasses (Le Houérou, 1980; Guerin et al., 1991; Ramirez et al., 1993; Papachristou \& Nastis, 1993; Moleele, 1998; Ngwa et al., 2000; Martinez, 2002b; Omphile et al., 2005; Papachristou et al., 2005) and Cuvier's gazelle have a more diverse diet composition (e.g. intermediate feeder) (Benamor et al., 2019). We hypothesized that the dietary overlap and its seasonal changes between Cuvier's gazelle and domestic (sheep/goats) would be generally high during certain seasons of the year. Subsequently, we predicted that diversity of the composition of Cuvier's gazelle diet would be higher than the other two herbivores studied. In response to the previous assumptions, we focused our research on the study of the annual dietary botanical composition, diversity and overlaps between Cuvier's gazelle, livestock in the forest of Djebel Messaâd. However, understanding the feeding niche of herbivores may help understand competitive interactions among herbivores and proper range management (Shipley, 1999). We hope this study would help in suggesting some management decisions affecting the gazelles in the Djebel Messaâd Forest and in other areas with similar ecological characteristics.

\section{Materials and methods}

\section{Study area}

This study was carried out in Djebel Messaâd Forest $\left(\mathrm{N} 35.03^{\circ}, \mathrm{E} 4.15^{\circ}\right)$, characterised by the presence of the Cuvier's gazelle: the presence of animal trails and pellets were the main criteria for selecting the study area. This study took place between September 2016 and August 2017 on the northern part of Djebel Messaâd Forest. Since Algeria is influenced by the sea, relief and elevation, its climate is classed as 'temperate extra-tropical Mediterranean', characterized by a long period of summer drought that varies from 3-4 months on the coast to 5-6 months on the high plains and more than 6 months in the Saharan Atlas (Yahi et al., 2011). The climate of Djebel Messaâd Forest is semi-arid Mediterranean type with a mean annual precipitation $(315.5 \mathrm{~mm})$ while the mean annual temperature varies from $10.4^{\circ} \mathrm{C}$ to $21.1^{\circ} \mathrm{C}$. Temperature extremes (minimum and maximum) were respectively $0.74^{\circ} \mathrm{C}$ in January and $34.0^{\circ} \mathrm{C}$ in July. The dry season lasts from the end of May to mid-September.

The Mediterranean basin is one of the world's major centers of plant diversity, where $10 \%$ of the world's higher plants can be found in an area representing $1.6 \%$ of the Earth's surface (Médail \& Quézel, 1997). Information on vegetation characteristics of the sites were obtained from different sources. The Algerian flora comprises approximately 4000 taxa in 131 families and 917 genera. There are 464 national endemics (387 species, 53 subspecies and 24 varieties) (Yahi et al., 2011).
Djebel Messaâd Forest is an Aleppo pine natural forest. The vegetation of the area is a Pinetum halepensis forest including Pistacia lentiscus, Rosmarinus officinalis, Globularia alypum, Hertia cheirifolia, Dorycnium suffruticosum, Fumana ericoides, Stipa tenacissima, Cistus libanotis, a Juniperetum phoenicea forest characterized by Artemisia herba alba, Lygeum spartum, Helianthemum cinereum, and a Quercetum ilicis forest in relatively cool parts or sites less impacted by farming and grazing, this includes Cistus villosus, Jasminum fruticans, Muscari atlanticum, Dactylis hispanica and Ampelodesma mauritanica (El-Attoui, 1996).

\section{Animals and diets}

The Cuvier's gazelle occupying the relatively dry forests of semi-arid Mediterranean type dominated by Pinus halepensis, Juniperus phoenicea, Tetraclinis articulata, Cedrus atlantica, Quercus ilex, Argania spinosa (Beudels et al., 2005). The study area is grazed by goats and sheep simultaneously, all year round following a traditional continuous grazing system. Several methods are currently available to researchers interested in herbivore diet composition. Martin (1970) give reviews of the various utilization techniques used in estimating diets of grazing animals. Food habits of the wild ungulates and livestock were investigated through dung analysis which has been widely used to study the diet of ungulates (Holechek et al., 1982; Martinez, 2002b; Kilonzo et al., 2005; Shrestha et al., 2005). Faecal analysis has received greater use for evaluating herbivore food habit's than any other procedure with the increased use of Microhistological techniques (Sparks \& Malechek, 1968). Microhistological analysis using faecal samples has several unique advantages, which account for its popularity as a research tool (Ward, 1970; Anthony \& Smith, 1974), and which is the method of choice in the present study. It's accuracy in estimating diet composition of grazing animals has shown to be well over $94 \%$ when comparisons were made with the actual species composition in forage mixtures (Holechek et al., 1982).

\section{Plant reference slides}

Following the method of (García-Gonzalez, 1983), Plant species samples were dried, separated into leaves, stems, fruits, etc. It consists essentially of scraping the plant fragment taken until leaving the epidermis transparent, rinsing in $\mathrm{NaClO}$, set up in glycerin solution $50 \%$. The diagnostic features of the plant epidermis such as cells, fibres, trichomes, pores, stomata, vessels, intercellular structures and cell walls from each reference slide were photographed using a camera fitted to an optical microscope at $(10 \times 10)$ and $(10 \times 40)$ magnification. Microscope slides of each plant species were made for reference collection. Each plant species was assigned to one of the following forage classes: (1) shrubs and trees, (2) grasses, (3) forbs. 
Collection and micro-histological analysis of faecal samples

Faecal samples were collected from September 2016 to August 2017. The dietary composition of the three different species under study was determined by analysis of faecal material using the micro-histological technique as described by Sparks \& Malechek (1968) and Dearden et al. (1975) and further developed by Holechek et al. (1982). The diet of livestock was also recorded through direct observation but Cuvier's gazelle, direct observations were not possible as the animals did not allow close approach.

During a one-year period, eight or ten pellets from each individual goat, sheep and Cuvier's gazelle were taken. Samples were collected on the last of each month along 4-7 km-long transects. According to Stewart \& Stewart (1971) who studied 10 faecal pellets per area and season, we randomly collected a total of six fresh pellet samples from six different pellet groups (individuals) per each sampling, month. The pellets were stored in paper sacks, then air-dried and oven-dried at $60^{\circ} \mathrm{C}$ for $24 \mathrm{~h}$. Pellets from each month for each of the species were thoroughly mixed to make one composite sample. From each composite sample three sub-samples were taken for analysis.

\section{Data analysis}

The diet composition of the three animal species for each month was then classified into shrubs and trees, grasses and forbs. Two factors that could influence the composition of epidermal fragments were considered: animal species (Cuvier's gazelle, sheep and goats); months [defined as four, 3-month periods: autumn (September-November), winter (December-February), spring (March-April), summer (May-July)].

Diet composition was expressed as average relative numerical abundance $(N \%)$ for each plant taxon. This last is the ratio of the number of fragments of a species or category $(n)$ to the total number of fragments of all plant taxa (Zaime \& Gautier, 1989).

$$
N \% \operatorname{taxon}_{i}=\left(n_{i} / N\right) \times 100 \quad \text { Equation } 1
$$

where $n$ is the number of individual fragments in the $i$ taxon of plant in a fecal sample, $N$ is the total number of identified plant fragments in a diet.

Food diversity $\left(H^{\prime}\right)$ of Cuvier's gazelle, sheep and goats were calculated on the basis of Shannon-Wiener index (Krebs, 1999).

$$
H^{\prime}=-\sum_{i=1}^{R} p_{i} \ln p_{i}
$$

Equation 2

where $p_{i}$ is the ratio of the number of individual fragments in the $i$ taxon of plant in a fecal sample $\left(n_{i}\right)$ to the total number of identified plant fragments in a diet $(N) . R$ is richness. High trophic diversity indices express high potential adaptability for an herbivore to select foods (Hansen \& Reid, 1975).
Pielou's Evenness index or Shannon's Equitability $\left(E_{H}\right)$ is obtained dividing the Shannon-Wiener Diversity Index by its maximum. Equitability varies between 0 and 1 .

$$
E_{H}=\frac{-\sum_{i=1}^{R} p_{i} \ln p_{i}}{\ln S}
$$

The trophic niche Overlap $\left(O_{i k}\right)$ of Cuvier's gazelle, sheep and goats were performed based on the food categories cited above. We calculated $\left(O_{j k}\right)$ with Pianka's index (Pianka, 1973):

$$
O_{j k}=\frac{\sum_{i}^{n} p_{i j} p_{i k}}{\sqrt{\sum_{i}^{n} p_{i j}^{2} \sum_{i}^{n} p_{i k}^{2}}}
$$

Equation 4

where $O_{j k}$ is the trophic niche overlap between species $j$ and species $k$; and $p_{i}$ is the biomass of the food item $i$. Dietary overlap values range from 0 (no overlap) to 1 (complete overlap).

\section{Results}

Over the whole annual cycle, a total of 48 food plant species were identified in fecal samples, 39 of which were found in Cuvier's gazelle, 29 and 36 from domestic sheep and goats respectively; 20 genera occurred in Cuvier's gazelle, domestic sheep and goat feces. Cuvier's gazelle and Goats maintained a high proportion of shrubs and trees in their diet. The principal foods were browses for goats (23.3-48.0\%) depending on the month (Tab. 3), grasses $(20.3-69.3 \%)$, forbs $(5.0-27.7 \%)$, and shrubs and trees (22.3-74.7\%) for Cuvier's gazelle (Tab. 1), and grasses (21.0-56.0\%) for sheep (Tab. 2). Goat and sheep diets consisted primarily of Wheat (Triticum turgidum), and secondarily of (Stipa tenacissima) (Tab. $2,3)$. Approximately $44 \%$ and $53 \%$ of goat and sheep diets respectively was accounted for by these two species.

Diet composition of Cuvier's gazelle

Diet of Cuvier's gazelle consisted of thirty-nine plant species; of which $52.6 \%$ were shrubs and trees, $38.1 \%$ grasses and $9.3 \%$ forbs (Tab. 1). The dominant shrubs and trees species included Artemisia herba alba, Pistacia terebinthus, Cistus salviifolius, Phillyrea media, Calicotome spinosa, Pinus halepensis, Cistus libanotis and major grass species were contributed by Stipa tenacissima (Tab. 1). Higher amount of shrubs and trees were found in the diet of gazelles from July to November. The forbs in Cuvier's gazelle diet was low during dry seasons (June-August) and higher during spring period (March-May). Grasses in Cuvier's diet was high during spring period, especially May $(69.3 \%)$. The fecal compositions of Cuvier's gazelle in autumn were characterized by smaller occupation of Stipa and greater occupation of Artemisia herba alba. The dietary compositions in summer were characterized by greater occupation of Pistacia terebinthus. 
Table 1. Shrubs and trees (ST), grasses (G) and forbs (F) plants in the annual diet composition of Cuvier's gazelle from the Djebel Messaâd Forest (M'Sila, Algeria), estimated by microhistological analysis of faecal samples. Values represent average relative numerical abundance $(N \%)$ of fragment frequency.

\begin{tabular}{|c|c|c|c|c|c|c|c|c|c|c|c|c|c|}
\hline \multirow{2}{*}{$\begin{array}{l}\text { Plant categories and } \\
\text { species }\end{array}$} & \multicolumn{3}{|c|}{ Autumn } & \multicolumn{3}{|c|}{ Winter } & \multicolumn{3}{|c|}{ Spring } & \multicolumn{3}{|c|}{ Summer } & \multirow{2}{*}{ Annual } \\
\hline & Sep & Oct & Nov & Dec & Jan & Feb & Mar & Apr & May & Jun & Jul & Aug & \\
\hline Shrubs and trees (ST) & 61.00 & 74.67 & 64.33 & 56.00 & 53.67 & 43.33 & 34.00 & 23.33 & 22.33 & 59.00 & 68.00 & 71.33 & 52.58 \\
\hline Artemisia herba alba & 9.67 & 8.00 & 11.67 & 3.33 & 5.00 & - & 5.00 & 5.00 & 8.00 & 14.67 & 23.67 & 16.67 & 9.22 \\
\hline Pistacia terebinthus & 7.67 & 4.67 & 4.00 & 4.33 & 3.33 & - & 1.67 & - & 0.33 & 24.00 & 26.67 & 23.00 & 8.31 \\
\hline Cistus salviifolius & 1.33 & 2.33 & 5.33 & 9.00 & - & 16.67 & 6.33 & 2.67 & - & 2.33 & - & 7.00 & 4.42 \\
\hline Phillyrea media & 6.00 & 6.33 & 12.33 & 2.33 & 9.33 & 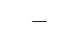 & 2.00 & 2.67 & - & 5.33 & 4.33 & - & 4.22 \\
\hline Calicotome spinosa & - & 5.33 & 8.33 & - & 9.67 & - & 3.00 & - & - & 3.00 & 9.67 & 7.00 & 3.83 \\
\hline Pinus halepensis & 12.00 & 7.67 & - & 4.00 & 13.00 & - & - & - & - & - & - & 4.33 & 3.42 \\
\hline Cistus libanotis & 0.33 & 9.33 & - & 7.00 & - & 19.33 & 4.67 & - & - & - & - & - & 3.39 \\
\hline Pistacia lentiscus & 4.00 & 8.00 & 7.67 & 3.00 & - & - & - & 0.67 & - & - & - & - & 1.94 \\
\hline Globularia alypum & 4.33 & 4.00 & 4.00 & 3.67 & 4.33 & - & - & 0.33 & - & - & - & - & 1.72 \\
\hline Thymus algeriensis & - & - & - & - & - & - & - & - & 9.33 & 3.67 & - & 7.67 & 1.72 \\
\hline Quercus ilex & - & 10.67 & - & 3.33 & 6.33 & - & - & - & - & - & - & - & 1.69 \\
\hline Juniperus phoenicea & 1.67 & 4.33 & - & 8.67 & - & - & - & 0.33 & - & - & - & - & 1.25 \\
\hline Lonicera implexa & 4.00 & - & 5.67 & - & - & 0.67 & - & 0.67 & - & - & - & 2.33 & 1.11 \\
\hline Undetermined 1 & 8.67 & - & - & - & - & - & - & 1.33 & - & 2.00 & - & - & 1.00 \\
\hline Artemisia absinthium & - & - & - & - & - & - & 1.33 & - & - & 1.67 & 3.67 & 3.33 & 0.83 \\
\hline Heliantemum croceum & - & - & - & - & - & 2.00 & 5.33 & 1.67 & - & - & - & - & 0.75 \\
\hline Rosmarinus officinalis & 0.33 & - & - & 3.67 & - & - & 4.67 & - & - & - & - & - & 0.72 \\
\hline Undetermined 2 & 0.33 & - & 4.00 & - & 2.67 & - & - & 1.33 & - & - & - & - & 0.69 \\
\hline Juniperus oxycedrus & - & 4.00 & - & 3.67 & - & - & - & - & - & - & - & - & 0.64 \\
\hline Others & 0.67 & - & 1.33 & - & - & 4.67 & - & 6.67 & 4.67 & 2.33 & - & - & 1.69 \\
\hline Grasses $(\mathrm{G})$ & 27.67 & 20.33 & 30.00 & 32.00 & 38.33 & 43.00 & 46.33 & 49.00 & 69.33 & 41.00 & 32.00 & 28.67 & 38.14 \\
\hline Stipa tenacissima & 9.67 & 20.33 & 19.67 & 32.00 & 38.33 & 29.00 & 7.33 & 11.00 & 14.00 & 36.67 & 24.33 & 27.67 & 22.50 \\
\hline Stipa parviflora & - & - & - & - & - & - & 26.67 & 18.33 & 25.33 & 0.67 & - & - & 5.92 \\
\hline Avena sativa & 13.33 & - & 5.33 & - & - & 6.67 & 9.00 & 5.67 & 6.00 & - & - & - & 3.83 \\
\hline Bromus madritensis & 3.00 & - & 1.67 & - & - & 4.67 & - & 12.00 & 14.33 & - & - & - & 2.97 \\
\hline Koeleria vallesiana & 1.00 & - & - & - & - & 2.67 & 3.33 & 2.00 & 9.67 & - & - & - & 1.56 \\
\hline Lygeum spartum & - & - & - & - & - & - & - & - & - & 2.00 & 5.67 & 1.00 & 0.72 \\
\hline Others & 0.67 & - & 3.33 & - & - & - & - & - & - & 1.67 & 2.00 & - & 0.64 \\
\hline Forbs $(\mathrm{F})$ & 11.33 & 5.00 & 5.67 & 12.00 & 8.00 & 13.67 & 19.67 & 27.67 & 8.33 & - & - & - & 9.28 \\
\hline Helianthemum sp. & 0.33 & - & - & 9.33 & - & 12.67 & 15.33 & 18.00 & 4.67 & - & - & - & 5.03 \\
\hline Plantago lanceolata & 4.33 & 5.00 & 5.67 & 1.33 & 8.00 & - & 0.33 & - & 3.67 & - & - & - & 2.36 \\
\hline Sedum sediforme & - & - & - & - & - & - & 3.33 & 8.67 & - & - & - & - & 1.00 \\
\hline Sisymbrium sp. & 6.67 & - & - & 1.33 & - & - & 0.67 & - & - & - & - & - & 0.72 \\
\hline Others & - & - & - & - & - & 1.00 & - & 1.00 & - & - & - & - & 0.17 \\
\hline Number of fragments & 300 & 300 & 300 & 300 & 300 & 300 & 300 & 300 & 300 & 300 & 300 & 300 & 3600 \\
\hline
\end{tabular}

$(-)$ : Not found in faeces.

Others: Plant species consumed by Cuvier's gazelle under $0.5 \%$. Shrubs and trees (Calligonum comosum, Fumana thymifolia, Undetermined 3, Atriplex canescens, Helianthemum lippii, Artemisia campestris); grasses (Bromus rubens, Cynodon dactylon, Undetermined 4); forbs (Undetermined 5).

\section{Diet composition of sheep}

The diet of domestic sheep was composed of $41.7 \%$ grasses, $24.6 \%$ shrubs and trees, $2.3 \%$ forbs and the remaining $31.4 \%$ is fodders (Tab. 2). About $40.0 \%$ of the diet was made of three grasses species: Stipa tenacissima $(25.3 \%)$, Hordeum vulgare $(9.2 \%)$ and Triticum turgidum $(4.9 \%)$. Domestic sheep fed on forbs during spring mainly in April (20.7\%) at the opposite of summer form June to August $(0.0 \%)$ when the consumption of grasses is the highest (40.0-56.0\%) respectively.

\section{Diet composition of goats}

Domestic goat's food consists of $37.4 \%$ shrubs and trees, $31.9 \%$ grasses, $2.2 \%$ forbs and the remaining $28.5 \%$ is fodders (Tab. 3). In spring (March-May), the diet was $(35.0-46.7 \%)$ shrubs and trees and this increased to $48.0 \%$ in summer (Aug). Species of shrubs and trees occurring in their diet included Pinus halepensis, Artemisia herba alba, Juniperus phoenicea, Pistacia terebinthus, Pistacia lentiscus, Juniperus oxycedrus, Quercus ilex, Cistus libanotis and Phillyrea media. The 
Table 2. Shrubs and trees (ST), grasses $(\mathrm{G})$, forbs $(\mathrm{F})$ and fodders (Fd) plants in the annual diet composition of domestic sheep from the Djebel Messaâd Forest (M'Sila, Algeria), estimated by microhistological analysis of faecal samples. Values represent average relative numerical abundance $(N \%)$ of fragment frequency.

\begin{tabular}{|c|c|c|c|c|c|c|c|c|c|c|c|c|c|}
\hline \multirow{2}{*}{$\begin{array}{c}\text { Plant categories and } \\
\text { species }\end{array}$} & \multicolumn{3}{|c|}{ Autumn } & \multicolumn{3}{|c|}{ Winter } & \multicolumn{3}{|c|}{ Spring } & \multicolumn{3}{|c|}{ Summer } & \multirow{2}{*}{ Annual } \\
\hline & Sep & Oct & Nov & Dec & Jan & Feb & Mar & Apr & May & Jun & Jul & Aug & \\
\hline Shrubs and trees (ST) & 20.00 & 4.00 & 17.33 & 18.00 & 7.33 & 34.67 & 47.33 & 20.67 & 57.00 & 20.67 & 23.67 & 24.67 & 24.61 \\
\hline Artemisia herba alba & - & - & - & - & 2.67 & 1.00 & 35.67 & 13.67 & 32.67 & 13.67 & 17.33 & 8.67 & 10.44 \\
\hline Pinus halepensis & 16.00 & - & 13.33 & 13.00 & 2.00 & 4.33 & 8.00 & - & 21.33 & 7.00 & - & 15.00 & 8.33 \\
\hline Juniperus phoenicea & 1.33 & - & - & 0.67 & - & 15.33 & - & - & 3.00 & - & 6.00 & 1.00 & 2.28 \\
\hline Pistacia terebinthus & - & 0.67 & 1.33 & 3.00 & - & 7.00 & - & - & - & - & - & - & 1.00 \\
\hline Pistacia lentiscus & - & 1.33 & - & - & - & 6.00 & - & - & - & - & - & - & 0.61 \\
\hline Juniperus oxycedrus & - & 1.67 & 2.67 & 1.33 & 1.33 & - & - & - & - & - & - & - & 0.58 \\
\hline Helianthemum lippii & - & - & - & - & - & - & 1.67 & 4.67 & - & - & - & - & 0.53 \\
\hline Phillyrea media & 2.67 & - & - & - & - & - & - & - & - & - & - & - & 0.22 \\
\hline Undetermined 2 & - & - & - & - & - & - & 1.33 & 1.33 & - & - & - & - & 0.22 \\
\hline Calligonum comosum & - & - & - & - & - & - & - & 1.00 & - & - & 0.33 & - & 0.11 \\
\hline Cistus salviifolius & - & - & - & - & - & 1.00 & - & - & - & - & - & - & 0.08 \\
\hline Globularia alypum & - & 0.33 & - & - & - & - & 0.67 & - & - & - & - & - & 0.08 \\
\hline Cistus libanotis & - & - & - & - & 0.67 & - & - & - & - & - & - & - & 0.06 \\
\hline Fumana thymifolia & - & - & - & - & 0.67 & - & - & - & - & - & - & - & 0.06 \\
\hline Grasses $(\mathrm{G})$ & 49.00 & 44.00 & 21.00 & 33.33 & 51.00 & 29.33 & 26.67 & 54.33 & 40.33 & 40.00 & 56.00 & 55.33 & 41.69 \\
\hline Stipa tenacissima & 19.00 & 40.00 & 15.67 & 22.67 & 26.33 & 17.67 & 22.67 & 49.00 & 26.33 & 14.67 & 22.00 & 27.67 & 25.31 \\
\hline Hordeum vulgare & 14.00 & 2.67 & 3.00 & 8.67 & 9.33 & 2.67 & - & - & 2.67 & 17.33 & 28.00 & 21.67 & 9.17 \\
\hline Triticum turgidum & 4.00 & - & - & - & 15.33 & 9.00 & 3.00 & - & 7.00 & 8.00 & 6.00 & 6.00 & 4.86 \\
\hline Bromus rubens & 4.67 & 1.33 & - & - & - & - & - & 5.33 & 1.33 & - & - & - & 1.06 \\
\hline Koeleria vallesiana & 6.67 & - & - & - & - & - & 1.00 & - & - & - & - & - & 0.64 \\
\hline Lygeum spartum & - & - & 2.33 & 2.00 & - & - & - & - & - & - & - & - & 0.36 \\
\hline Avena sativa & - & - & - & - & - & - & - & - & 3.00 & - & - & - & 0.25 \\
\hline $\begin{array}{l}\text { Ampelodesmos } \\
\text { mauritanicus }\end{array}$ & 0.67 & - & - & - & - & - & - & - & - & - & - & - & 0.06 \\
\hline Forbs $(\mathrm{F})$ & - & 0.33 & - & - & 1.00 & - & 1.00 & 23.00 & 1.67 & - & - & - & 2.25 \\
\hline Helianthemum sp. & - & - & - & - & - & - & - & 20.67 & 0.67 & - & - & - & 1.78 \\
\hline Plantago albicans & - & 0.33 & - & - & - & - & 1.00 & - & 1.00 & - & - & - & 0.19 \\
\hline Sedum sediforme & - & - & - & - & - & - & - & 1.67 & - & - & - & - & 0.14 \\
\hline Plantago lanceolata & - & - & - & - & 1.00 & - & - & - & - & - & - & - & 0.08 \\
\hline Matthiola lunata & - & - & - & - & - & - & - & 0.67 & - & - & - & - & 0.06 \\
\hline Fodders (Fd) & 31.00 & 51.67 & 61.67 & 48.67 & 40.67 & 36.00 & 25.00 & 2.00 & 1.00 & 39.33 & 20.33 & 20.00 & 31.44 \\
\hline $\begin{array}{l}\text { Bran of Triticum } \\
\text { turgidum }\end{array}$ & 31.00 & 50.33 & 61.67 & 48.00 & 31.33 & 20.67 & 20.33 & 2.00 & - & 33.33 & 13.67 & 18.00 & 27.53 \\
\hline $\begin{array}{l}\text { Straws of Hordeum } \\
\text { vulgare }\end{array}$ & - & 1.33 & - & 0.67 & 9.33 & 15.33 & 4.67 & - & 1.00 & 6.00 & 6.67 & 2.00 & 3.92 \\
\hline Number of fragments & 300 & 300 & 300 & 300 & 300 & 300 & 300 & 300 & 300 & 300 & 300 & 300 & 3600 \\
\hline
\end{tabular}

$(-)$ : Not found in faeces.

dominant grasses in their diet included Stipa tenacissima, Hordeum vulgare, Triticum turgidum, Bromus rubens and Stipa parviflora. Seasonally, the goats were found to concentrate on shrubs and trees. The fecal compositions of goats in summer were characterized by smaller occupation of Pistacia terebinthus and greater occupation of Hordeum vulgare.

Food diversity and equitability of gazelles and livestock

The seasonal diversity values were invariably high for Cuvier's gazelle in autumn (3.69) and generally decreased from winter (3.03) to summer (2.69), while relatively low for both sheep and goats (Fig. 1). Mean annual plant diversity for three animal species within each season was 2.84. Trophic diversity generally ranged between (2.56 and 3.87) for the Cuvier's gazelle, with high value (3.87) in September (Fig. 2A). While, domestic sheep and goats have slightly lower diversity values (1.62-3.03) and (2.23-3.60), respectively (Fig. 2B, 2C). Equitability values varied from 0.71 to 0.94 for the Cuvier's gazelle, (0.62-0.92) and (0.67-0.89) for sheep and goats respectively (Fig. $2 \mathrm{~A}, 2 \mathrm{~B}, 2 \mathrm{C})$. 
Table 3. Shrubs and trees (ST), grasses $(\mathrm{G})$, forbs $(\mathrm{F})$ and fodders $(\mathrm{Fd})$ plants in the annual diet composition of goats from the Djebel Messaâd Forest (M'Sila, Algeria), estimated by microhistological analysis of faecal samples. Values represent average relative numerical abundance $(N \%)$ of fragment frequency.

\begin{tabular}{|c|c|c|c|c|c|c|c|c|c|c|c|c|c|}
\hline \multirow{2}{*}{$\begin{array}{c}\text { Plant categories and } \\
\text { species }\end{array}$} & \multicolumn{3}{|c|}{ Autumn } & \multicolumn{3}{|c|}{ Winter } & \multicolumn{3}{|c|}{ Spring } & \multicolumn{3}{|c|}{ Summer } & \multirow{2}{*}{ Annual } \\
\hline & Sep & Oct & Nov & Dec & Jan & Feb & Mar & Apr & May & Jun & Jul & Aug & \\
\hline Shrubs and trees (ST) & 39.67 & 34.00 & 34.67 & 24.33 & 23.33 & 36.33 & 41.33 & 46.67 & 35.00 & 41.33 & 44.67 & 48.00 & 37.44 \\
\hline Pinus halepensis & 6.33 & 7.33 & 5.33 & 2.67 & 3.00 & 6.33 & 6.67 & 8.67 & 9.33 & 19.33 & 17.00 & 29.33 & 10.11 \\
\hline Artemisia herba alba & - & - & - & - & 1.67 & - & 4.67 & 13.67 & 14.67 & 13.33 & 12.67 & 7.67 & 5.69 \\
\hline Juniperus phoenicea & 6.00 & 4.67 & 4.00 & - & 5.00 & 5.67 & 8.67 & 8.33 & 4.00 & 4.33 & 2.33 & - & 4.42 \\
\hline Pistacia terebinthus & 8.67 & 7.33 & 6.33 & - & 1.00 & 2.67 & 8.67 & 6.67 & 1.67 & - & - & - & 3.58 \\
\hline Pistacia lentiscus & 11.00 & 9.00 & 6.00 & - & - & 2.33 & - & - & - & 2.67 & 6.33 & 5.00 & 3.53 \\
\hline Juniperus oxycedrus & 1.00 & 1.00 & 3.33 & 8.33 & 5.67 & 6.33 & - & - & - & - & - & - & 2.14 \\
\hline Quercus ilex & 6.67 & 4.67 & 3.00 & 4.00 & 1.00 & - & - & - & - & - & - & - & 1.61 \\
\hline Cistus libanotis & - & - & - & - & 0.67 & - & 3.33 & 3.00 & 1.67 & 1.67 & 4.67 & 3.67 & 1.56 \\
\hline Phillyrea media & - & - & 6.00 & - & 1.00 & 6.33 & - & - & - & - & - & - & 1.11 \\
\hline Rosmarinus officinalis & - & - & - & 5.00 & 2.33 & 3.00 & - & - & - & - & - & - & 0.86 \\
\hline Cistus salviifolius & - & - & - & 0.67 & - & 1.00 & 3.67 & 1.33 & 1.67 & - & - & - & 0.69 \\
\hline Globularia alypum & - & - & - & 3.67 & 2.00 & 2.67 & - & - & - & - & - & - & 0.69 \\
\hline Calligonum comosum & - & - & - & - & - & - & - & 2.00 & - & - & 1.67 & 2.33 & 0.50 \\
\hline Helianthemum lippii & - & - & - & - & - & - & - & 3.00 & 2.00 & - & - & - & 0.42 \\
\hline Artemisia absinthium & - & - & - & - & - & - & 3.33 & - & - & - & - & - & 0.28 \\
\hline Fumana thymifolia & - & - & - & - & - & - & 2.33 & - & - & - & - & - & 0.19 \\
\hline Calicotome spinosa & - & - & 0.67 & - & - & - & - & - & - & - & - & - & 0.06 \\
\hline Grasses (G) & 21.00 & 13.67 & 6.67 & 34.33 & 28.33 & 32.67 & 36.67 & 38.67 & 48.00 & 46.33 & 36.00 & 40.33 & 31.89 \\
\hline Stipa tenacissima & 8.00 & 12.67 & 6.67 & 28.33 & 15.33 & 26.33 & 27.67 & 23.00 & 30.67 & 18.33 & 9.00 & 13.33 & 18.28 \\
\hline Hordeum vulgare & - & - & - & 2.33 & 4.00 & 2.67 & - & - & 5.67 & 23.00 & 26.00 & 22.33 & 7.17 \\
\hline Triticum turgidum & - & - & - & - & 4.33 & 3.67 & 2.33 & 2.00 & 4.33 & 5.00 & 1.00 & 4.67 & 2.28 \\
\hline Bromus rubens & 11.33 & 0.33 & - & - & - & - & - & 2.67 & 3.33 & - & - & - & 1.47 \\
\hline Stipa parviflora & - & - & - & 1.00 & - & - & 6.67 & 5.00 & - & - & - & - & 1.06 \\
\hline Vulpia $\mathrm{sp.}$ & - & - & - & - & 3.00 & - & - & 1.67 & - & - & - & - & 0.39 \\
\hline Koeleria vallesiana & 1.67 & 0.67 & - & - & - & - & - & - & - & - & - & - & 0.19 \\
\hline Bromus madritensis & - & - & - & - & - & - & - & 4.33 & - & - & - & - & 0.36 \\
\hline Avena sativa & - & - & - & - & - & - & - & - & 2.67 & - & - & - & 0.22 \\
\hline Cynodon dactylon & - & - & - & - & - & - & - & - & 1.33 & - & - & - & 0.11 \\
\hline $\begin{array}{l}\text { Ampelodesmos } \\
\text { mauritanicus }\end{array}$ & - & - & - & 2.00 & 1.00 & - & - & - & - & - & - & - & 0.25 \\
\hline Lygeum spartum & - & - & - & 0.67 & 0.67 & - & - & - & - & - & - & - & 0.11 \\
\hline Forbs $(\mathrm{F})$ & - & - & - & 0.33 & - & - & 11.33 & 14.67 & - & - & - & - & 2.19 \\
\hline Helianthemum sp. & - & - & - & - & - & - & 8.67 & 9.67 & - & - & - & - & 1.53 \\
\hline Sedum sediforme & - & - & - & - & - & - & - & 2.67 & - & - & - & - & 0.22 \\
\hline Sisymbrium sp. & - & - & - & - & - & - & 2.67 & - & - & - & - & - & 0.22 \\
\hline Matthiola lunata & - & - & - & - & - & - & - & 2.33 & - & - & - & - & 0.19 \\
\hline Pituranthos scoparius & - & - & - & 0.33 & - & - & - & - & - & - & - & - & 0.03 \\
\hline Fodders $(\mathrm{Fd})$ & 39.33 & 52.33 & 58.67 & 41.00 & 48.33 & 31.00 & 10.67 & - & 17.00 & 12.33 & 19.33 & 11.67 & 28.47 \\
\hline $\begin{array}{l}\text { Bran of Triticum } \\
\text { turgidum }\end{array}$ & 39.33 & 49.33 & 58.67 & 36.00 & 34.67 & 21.00 & 10.67 & - & 15.33 & 12.33 & 17.67 & 11.67 & 25.56 \\
\hline $\begin{array}{l}\text { Straws of Hordeum } \\
\text { vulgare }\end{array}$ & - & 3.00 & - & 5.00 & 13.67 & $1-$ & - & - & 1.67 & - & 1.67 & - & 2.92 \\
\hline Number of fragments & 300 & 300 & 300 & 300 & 300 & 300 & 300 & 300 & 300 & 300 & 300 & 300 & 3600 \\
\hline
\end{tabular}

$(-)$ : Not found in faeces.

\section{Dietary overlap of Cuvier's gazelle and} livestock

Trophic niche overlap between all pairs of species are presented in Table 4. Shared species (21) represented a higher proportion of dietary items for Cuvier's gazelle $(N \%=76.9)$ than for sheep $(N \%=54.0)($ Tab. 1,2$)$.
While shared 28 species, a very higher proportion of those used by Cuvier's gazelle $(N \%=91.4)$ than by goats $(N \%=61.2)$ (Tab. 1,3). The overlap of diets was greatest during summer and spring season, while the lowest in autumn season for each animal combination. Annual overlap confirmed that, domestic sheep and goats had 


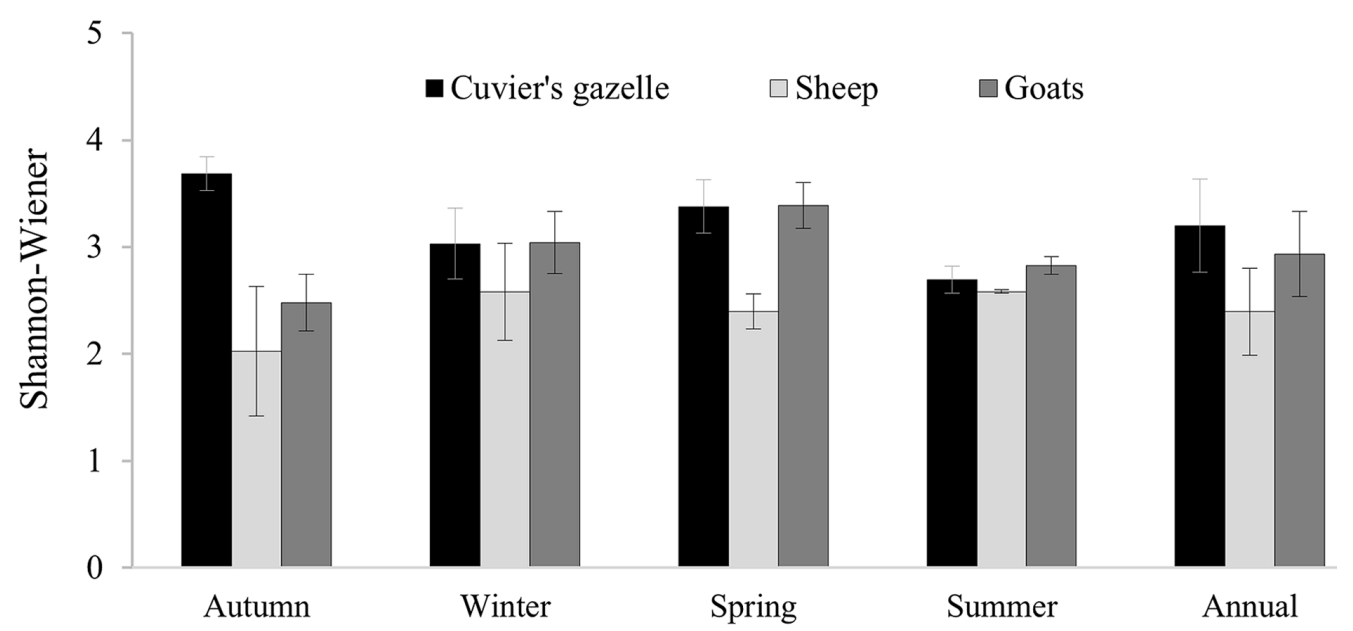

Fig. 1. Seasonal diversity of plant species found in the diet of the Cuvier's gazelle, domestic sheep and goats in the Djebel Messaâd Forest (M'Sila, Algeria).
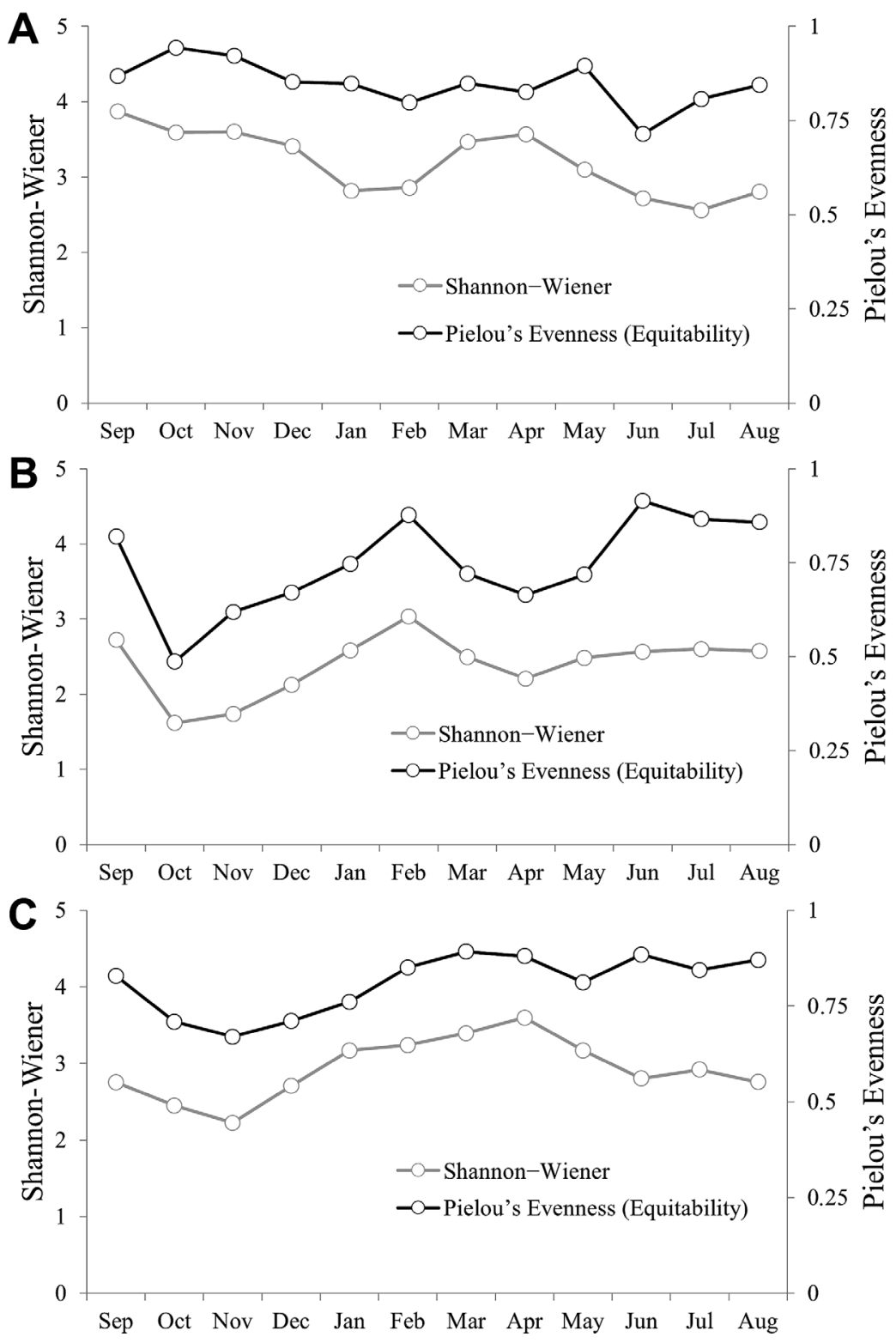

Fig. 2. Monthly diversity and equitability of plant species found in the diet of the Cuvier's gazelle Gazella cuvieri (A), sheep (B) and goats (C), represented by the Shannon-Wiener and Pielou's Evenness index. 
very similar diets $(0.82)$ and both of them had relatively less diet overlap with Cuvier's gazelle (0.39) (Tab. 4). In autumn, Cuvier's gazelle had less amount of diet overlap with sheep (0.30) but in summer diet overlap of Cuvier's gazelle with sheep (0.46) became relatively high. In spring, Cuvier's gazelle and goats showed relatively high niche overlap (0.49) but in autumn diet overlap of Cuvier's gazelle with goats became low $(0.22)$.

Table 4. Trophic niche overlap using Pianka's index among Cuvier's gazelle, domestic sheep and goats in the Djebel Messaâd Forest (M'Sila, Algeria). $O_{j k}$ — Pianka's niche overlap index; $S D$ - standard deviation.

\begin{tabular}{|l|c|c|c|c|c|c|}
\hline \multirow{2}{*}{ Species } & \multirow{2}{*}{$\begin{array}{c}\text { Shared } \\
\text { species }\end{array}$} & Autumn & Winter & Spring & Summer & Annual \\
\cline { 4 - 7 } & $O_{j k} \pm S D$ & $O_{j k} \pm S D$ & $O_{j k} \pm S D$ & $O_{j k} \pm S D$ & $O_{j k} \pm S D$ \\
\hline Cuvier's gazelle - sheep & 21 & $0.3 \pm 0.13$ & $0.41 \pm 0.08$ & $0.37 \pm 0.17$ & $0.46 \pm 0.09$ & $0.39 \pm 0.12$ \\
\hline Cuvier's gazelle — goats & 28 & $0.22 \pm 0.08$ & $0.46 \pm 0.08$ & $0.49 \pm 0.11$ & $0.37 \pm 0.09$ & $0.39 \pm 0.09$ \\
\hline
\end{tabular}

\section{Discussion}

Dietary selection of Cuvier's gazelle

Analysis of faecal samples revealed that Cuvier's gazelle fed on a wide variety of plant species, similar to results from studies in Algeria (Talbi, 1989; Sellami, 1999; Benamor et al., 2019). With $52.6 \%$ of shrubs and trees, $38.1 \%$ of grasses and $9.3 \%$ of forbs, our results corroborate those obtained by Arbouche et al. (2012) by direct observation at Djebel Metlili in the Belezma National Park, Algeria. From faeces analysis shrubs accounted for $77.3 \%$ and $36.1 \%$ of the diet in Djebel El Achch (Talbi, 1989) and Mergueb Nature Reserve (Sellami, 1999) respectively.

Graminoids, especially Stipa tenacissima, constituted a large portion of the diet of the Cuvier's gazelle from December to February (wet season) and from June to August (dry season) support by several study such as Bouredjli (1989) in the Mergueb Nature Reserve (M'Sila, Algeria) and Talbi (1989) in Djebel El Achch, Algeria, while shrubs were more often used in autumn from September to November (fall season) and from June to August (Stelfox \& Hudson, 1986). The results indicate that the Cuvier's gazelle is mixed feeder that select both grasses and browses (Hofmann \& Stewart, 1972). In this area the Cuvier's gazelle has been seen to feed on such grasses as Stipa tenacissima, Bromus rubens, Cynodon dactylon, shrubs and trees as Artemisia herba alba, Thymus algeriensis, Fumana thymifolia, Helianthemum lippii, Artemisia campestris and forbs as Sedum sediforme support (Talbi, 1989; Sellami, 1999; Benamor et al., 2019). During dry season the amounts of dicotyledon species consumed by the Cuvier's gazelle increase, a feature also common to African gazelles (Carlisle \& Ghorbial, 1968; Bell, 1970; Field \& Blankenship, 1973) and the mountain gazelle (Baharav, 1981). Furthermore, a relatively high level of shrubs and trees $(52.6 \%)$ in the diet of Cuvier's gazelle was observed by Ait Baamrane et al. $(2012,2017)$ for the Dorcas gazelle in M'Sabih Talaa Reserve (Morocco). Our data showed a high consumption and selection of forbs in spring
(April) such as Helianthemum sp., Plantago lanceolata, Sedum sediforme. This high value is corroborated those obtained by Ait Baamrane (2017).

Food diversity in the diet of Cuvier's gazelle and livestock

The diversity of plant species eaten by each herbivore may constitute a useful parameter in ecological comparisons of sympatric species since it expresses the food niche breadth and it complements the studies on overlap and competition (Schoener, 1971; Hurtubia, 1973). The significant differences in diet diversity between the animal species indicated that Cuvier's gazelle tended to have a wide variety of plant species in their diets (Kilonzo et al., 2005). The high number of plant species (39 in the present study) in the Cuvier's gazelle diet indicates that this species has many trophic connexions with other species of the area. Diet studies have typically shown large seasonal variation in the diets of sheep and goats (Malechek \& Leinweber, 1972, Bryant et al., 1979). The diversity averaged was a little high (2.58) for sheep during the summer (Mphinyane et al., 2015). While, goats have slightly higher food diversity values (2.23 and 3.60), with high values of equitability (0.89) in March. The diversity averaged was high (3.39) for goats during the spring support (Mphinyane et al., 2015). Trophic diversity averaged was higher (3.20) for Cuvier's gazelle than for sheep and goats (2.40 and $2.93)$, respectively over the year. This means that in this area, the livestock were more specialized with respect to food plants while the Cuvier's gazelle drew their food from a wider variety of the available resources (Schwartz \& Ellis, 1981). Differences included a higher diversity and equitability, lower forbs proportion, and higher shrubs and trees proportions in the Cuvier's gazelle diet. The wide spectrum of plant genera foraged reflects the relative adaptation of the herbivores to their habitat (Hansen et al., 1985). When plant diversity was high, the diet selection pattern of herbivore may be more beneficial to maintaining high plant diversity (Wang et al., 2011). 


\section{Livestock and dietary overlap}

This paper focused on the results of a study of the interactions between Cuvier's gazelle and livestock in Djebel Messaâd Forest. Data on interactions between wildlife and domestic animals suggest that spatial segregation between large herbivores and livestock is likely to occur because of direct competition between species (La Morgia \& Bassano, 2009). Diet overlaps between Cuvier's gazelle and livestock (sheep/goats) were generally moderate throughout the study period. These can, however, be expected to increase during periods of forage scarcity when opportunities of forage selection are restricted by limited species diversity and availability (Mphinyane et al., 2015). The diet of domestic sheep was dominated by grasses, confirming that this ungulate is primarily grazers (Schwartz \& Ellis, 1981; Squires, 1982; Ghosh et al., 1986; Martinez, 2002b; Kilonzo et al., 2005). The dominance of shrubs and trees species in the diet of goats confirms that they prefer browse (Le Houérou, 1980; Ramirez et al., 1993; Mphinyane et al., 2015).

A high dietary overlap can imply competition if resources are limited (Schoener, 1983; de Boer \& Prins, 1990; Putman et al., 1993). The summer diet of sheep was mainly based on grasses, but it also included shrubs and trees species (La Morgia \& Bassano, 2009). Browse component in sheep diets increased during the dry season, while in the wet season, sheep selected mainly grasses and forbs (Ekaya, 1991; Pfister \& Malechek, 1986). Stipa were important food items for gazelles and domestic sheep during summer (Harris \& Miller, 1995). Since the Cuvier's gazelle and domestic sheep had a large overlap in their summer (June-August) diets $\left(O_{j k}=0.46\right)$, there was a relatively high competition for food resources in Djebel Messaâd Forest during this season. The grasses in goat's diet was relatively high $(36.7-48.0 \%)$ during spring, several other studies have reported the extensive, but highly seasonal, use of grasses by goats (Malechek \& Leinweber, 1972, Bryant et al., 1979). Competition appeared to be potentially greatest between Cuvier's gazelle and goats during spring $\left(O_{j k}=0.49\right)$ and winter $\left(O_{j k}=0.47\right)$. In fall season (September-November) the diet of sheep was mostly graminoids while goats more on browse (shrubs and trees) and diet of Cuvier's gazelle was mixed.

Livestock there were a very high overlap in the diets over the year. Diets overlapped strongly for bran of Triticum turgidum, Stipa tenacissima, Pinus halepensis, Hordeum vulgare, Artemisia herba alba. The average monthly diet similarity between livestock $\left(O_{j k}=0.82\right)$ was very higher than that of both sheep and goats versus Cuvier's gazelle. Thirwood (1981) considers grazing by livestock among the major causes of forest degradation. Also, livestock possess the potential not only to compete for forage with wild species, but also to exclude them from desired sites due to their mere presence (Harris \& Miller, 1995).

This study clearly established the dietary overlap between Cuvier's gazelle and livestock, a first step towards assessing competitive interactions. Several authors have suggested that forage shortages could cause higher than normal overlap in food habits (Hansen et al., 1985). Thus, our study conforms to the idea, if we look at the high consumption of Fodders provided to livestock throughout the year. However, these data remain insufficient until the trophic preferences of these livestock are studied away from the fodders provided by the herders.

\section{Conclusion}

Previous study on dietary overlap has concentrated on establishing the existence of dietary competition and requirements for domestic and wild herbivores. The dietary composition of the three different herbivores under study was examined by analysis of faecal pellets using the micro-histological technique. The majority of the species of grasses, forbs, shrubs and trees preferred by the Cuvier's gazelle are those which in the study area are recorded as being selected by livestock. We reported that the values of diet diversity and equitability were high for Cuvier's gazelle, and concluded that this gazelle exhibited a higher dietary diversity than livestock. On the basis of these preliminary findings it appears that in terms of species selected, the diet of these three species of ungulates is largely overlapping, if we take into account the high consumption of Fodders provided to livestock throughout the year. It is not possible to make definitive conclusions about interspecific competition from these data.

This study was carried out without any external financial support. The study gazelles were observed in natural habitat without any capture or experiment.

\section{References}

Ait Baamrane M.A., Shehzad W., Ouhammou A., Abbad A., Naimi M., Coissac E., Taberlet P. \& Znari M. 2012. Assessment of the food habits of the Moroccan Dorcas gazelle in M'Sabih Talaa, West Central Morocco, using the trnL approach // PLoS ONE. Vol.7. No.4. e35643.

Ait Baamrane M.A., Znari M. \& Bellout S. 2017. Evaluation du régime alimentaire de la Gazelle dorcas du Maroc Gazella dorcas massaesyla dans la réserve M'Sabih Talaa par analyse Microhistologique// Go-South Bulletin. Vol.14. P.125-132.

Anthony R.G. \& Smith N.S. 1974. Comparison of rumen and fecal analysis to describe deer diets // Journal of Wildlife Management. Vol.38. P.535-540.

Arbouche Y., Arbouche H.S., Arbouche F.A. \& Arbouche R. 2012. Valeur fourragère des espèces prélevées par Gazella cuvieri Ogilby, 1841 au niveau du Djebel Metlili (Algérie) // Archivos de Zootecnia. Vol.61. No.233. P.145-148.

Baharav D. 1981. Food habits of the mountain gazelle in semi-arid habitats of eastern lower Galilée, Israel // Journal of Arid Environments. Vol.4. No.1. P.63-69.

Bailey D.W. 1995. Daily section of feeding areas by cattle in heterogeneous environment // Applied Animal Behaviour Science. Vol.45. P.183-200. 
Bell R.H.V. 1970. The use of the herb layer by grazing ungulates in the Serengeti // Watson A. (eds.). Animal Population in Relation to Their Food Resources. Oxford: Blackwell Scientific. P.111-124.

Belsky A.J. \& Gelbard J.L. 2000. Livestock Grazing and Weed Invasions in the Arid West. Portland: Oregon Natural Desert Association. $31 \mathrm{p}$.

Benamor N., Bounaceur F., Baha M. \& Aulagnier S. 2019. First data on the seasonal diet of the vulnerable Gazella cuvieri (Mammalia: Bovidae) in the Djebel Messaâd forest, northern Algeria // Folia Zoologica. Vol.68. No.4. P.253-260.

Beudels R.C., Devillers P., Lafontaine R.-M., Devillers Terschuren J. \& Beudels M.-O. 2005. Sahelo-Saharan Antelopes: Status and Perspectives // Report on the conservation status of the six Sahelo-Saharan Antelopes, 2nd ed., UNEP/ CMS Secretariat, Bonn, Switzerland. 120 p.

Bhattacharya T., Kittur S., Sathyakumar S. \& Rawat G.S. 2012. Diet overlap between wild ungulates and domestic livestock in the greater Himalaya: implications for management of grazing practices // Proceedings of the Zoological Society. Vol.65. No.1. P.11-21.

Bounaceur F., Boualem A., Benamor N., Fellous A., Benkheira A., Bissaad F.Z. \& Aulagnier S. 2016. Updated distribution and local abundance of the endangered Cuvier's gazelle (Mammalia, Bovidae) in Algeria // Folia Zoologica. Vol.65. P.233-238.

Bouredjli H.A. 1989. Eléments d'écoethologie de la gazelle de Cuvier: Gazella cuvieri (Ogilby, 1841) dans la réserve naturelle de Mergueb (M'Sila) et son statut en Algérie] // Thèse Ing., Institut National Agronomique El Harrach, Algérie. 88 p.

Bryant F.C., Kothmann M.M. \& Merrill L.B. 1979. Diets of sheep, Angora goats, Spanish goat and white-tailed deer under excellent range conditions // Journal of Range Management. Vol.32. P.412-417.

Carlisle D.B. \& Ghorbial L.I. 1968. Food and water requirements of Dorcas gazelle in the Sudan // Mammalia. Vol.32. No.4. P.570-576.

Coe P.K., Johnson B.K., Kern J.W., Findholt S.L., Kie J.G. \& Wisdom M.J. 2001. Responses of elk and mule deer to cattle in summer// Journal of Range Management. Vol.54. P.A51-A76.

Cuzin F. 2003. Les Grands Mammifères du Maroc Méridional (Haut Atlas, Anti Atlas, Sahara). Distribution, Écologie et Conservation] // PhD Thesis, École Pratique des Hautes Études, Montpellier, France. 349 p.

De Smet K. 1991. Cuvier's gazelle in Algeria // Oryx. Vol.25. No.2. P.99-104.

De Boer W.F. \& Prins H.H.T. 1990. Large herbivores that strive mightily but eat and drink as friends // Oecologia. Vol.82. P.264-274.

Dearden B.L., Pegau R.E. \& Hansen R.M. 1975. Precision of microhistological estimates of ruminant food habits // Journal of Wildlife Management. Vol.39. No.2. P.402-407.

Ekaya W.N. 1991. Forage preferences of livestock on a semi-and range in south-eastern Kenya // M.Sc. Thesis, University of Nairobi, Kenya. 130 p.

El-Attoui A. 1996. Etude phytoécologique et cartographie de la végétation steppique par utilisation de télédétection (Cas, Daïra de Djebel Messaâd)] // Mém. Ing, Institut Agronomique, Université de Sétif, Algérie. 150 p.
Field C.R. \& Blankenship L.H. 1973. Nutrition and reproduction of Grant's and Thomson's gazelles, Coke's hartebeest and giraffe in Kenya // Journal of Reproduction and Fertility. Supplement Vol.19. P.287-301.

Fleischner T.L. 1994. Ecological costs of livestock grazing in western North America // Biological Conservation. Vol.8. P.629-644.

Freschi P., Fascetti S., Riga F., Cosentino C., Rizzardini G. \& Musto M. 2016. Diet composition of the Italian roe deer (Capreolus capreolus italicus) (Mammalia: Cervidae) from two protected areas // European Zoological Journal. Vol.84. P.34-42.

García-Gonzalez R. 1983. Epidermis foliares de algunas especies de Festuca. Poa y Bellardiochloa en el Pirineo Occidental // Anales del Jardín Botánico de Madrid. Vol.39. No.2. P.389-404.

Ghosh P.K., Goya S.P.I. \& Bohra H.C. 1986. Habitat utilization by wild and domestic ungulates: a case study in a desert biome // Joss P.J., Lynch P.W. \& Wiliams O.B. (eds.). Rangelands: a resource under siege, proceedings of the Second International Rangeland Congress, Cambridge University Press. P.549-550.

Gordon I.J. \& Illius A.W. 1988. Incisor arcade structure and diet selection in ruminants // Functional Ecology. Vol.2. P.15-22.

Guerin H., Friot D., Mbaye N. \& Richard D. 1991. Alimentation des ruminants domestiques sur pâturages naturels sahéliens et Sahélo-soudaniens. Etude méthodologique de la région du Ferlo au Sénégal. Maison Alfort, France: IEMVT. 336 p.

Hansen R.M. \& Reid L.D. 1975. Diet overlap of deer, elk, and cattle in Southern Colorado // Journal of Range Management. Vol.28. P.43-47.

Hansen R.M., Mugambi M.M. \& Bauni S.M. 1985. Diets and trophic ranking of ungulates of the northern Serengeti // Journal of Wildlife Management. Vol.49. No.3. P.823-829.

Harris R.B. \& Miller D.J. 1995. Overlap in summer habitats and diets of Tibetan Plateau ungulates // Mammalia. Vol.59. No.2. P.197-212

Hobbs N.T., Baker D.L. Gill R.B. 1983. Comparative nutritional ecology of montane ungulates during winter // Journal of Wildlife Management. Vol.47. No.1. P.1-16.

Hofmann R.R. 1989. Evolutionary steps of ecophysiological adaptation and diversification of ruminants: a comparative view of their digestive system // Oecologia. Vol.78. No.4. P.443-457.

Hofmann R.R. \& Stewart D.R.M. 1972. Grazer or browser: a classification based on the stomach structure and feeding habits of East African ruminants // Mammalia. Vol.36. No.2. P.226-240.

Holechek J.L., Vavra M. \& Pieper R.D. 1982. Botanical composition determination of range herbivore diets: a review // Journal of Range Management. Vol.35. P.309-315.

Hurtubia J., 1973. Trophic diversity measurement in sympatric predatory species // Ecology. Vol.54. P.885-890.

IUCN. 2016. The IUCN Red List of Threatened Species 2016: e.T8967A50186003.

Jarman P.J. 1974. The social organisation of antelope in relation to their ecology // Behaviour. Vol.48. No.1. P.215-267.

Kilonzo J.M., Ekaya W.N. \& Kinuthia R.N. 2005. Feeding characteristics of sheep (Ovis aries) and Grant's gazelles (Gazella granti) on Kapiti ranch, Kenya // Journal of Range \& Forage Science. Vol.22. No.1. P.1-10. 
Kingdon J. 1997. The Kingdon Field Guide to African Mammals. San Diego: Academic Press. 496 p.

Krebs C.J. 1999. Ecological Methodology. 2nd edn. Menlo Park: Benjamin Cummings. 620 p.

La Morgia V. \& Bassano B. 2009. Feeding habits, forage selection, and diet overlap in Alpine chamois (Rupicapra rupicapra L.) and domestic sheep // Ecological Research. Vol.24. No.5. P.1043-1050.

Le Houérou H.N. 1980. The role of browse in the management of natural grazing lands // Le Houérou H.N. (eds.). Browse in Africa, the Current state of Knowledge. Addis Ababa: ILCA. P.329-339.

Lerp H., Wronski T., Plath M., Schröter A. \& Pfenninger M. 2013. Phylogenetic and population genetic analyses suggest a potential species boundary between mountain (Gazella gazella) and Arabian gazelles (G. arabica) in the Levant // Mammalian Biology. Vol.78. No.5. P.383-386.

MacNally R.C. 1983. On assessing the significance of interspecific competition to guild structure // Ecology. Vol.64. No.6. P.1646-1652.

Malechek J.C. \& Leinweber C.L. 1972. Forage selectivity by goats on lightly and heavily grazed ranges // Journal of Range Management. Vol.25. P.105-111.

Martin S.C. 1970. Determining animal consumption // Range and Wildlife Habitat Evaluation: A Research Symposium, U.S. Department of Agriculture, Forest Service, Miscellaneous Publication. No.1147. P.93-100.

Martinez T.M. 2001. The feeding strategy of Spanish ibex (Capra pyrenaica) in the northern Sierra de Gredos (central Spain) // Folia Zoologica. Vol.50. P.257-270.

Martinez T.M. 2002b. Summer feeding strategy of Spanish ibex (Capra pyrenaica) and domestic sheep (Ovis aries) in southeastern Spain // Acta Theriologica. Vol.47. P.479-490.

Médail F. \& Quézel P. 1997. Hot-spots analysis for conservation of plant biodiversity in the Mediterranean Basin // Annals of the Missouri Botanical Garden. Vol.84. No.1. P.112-127.

Mishra C., Van Wieren S.E., Ketner P., Heitkönig I.M.A. \& Prins H.H.T. 2004. Competition between domestic livestock and wild bharal Pseudois nayaur in the Indian Trans-Himalaya // Journal of Applied Ecology. Vol.41. No.2. P.344-354

Moleele N.M. 1998. Encroacher woody plant browses as feed for cattle. Cattle diet composition for three seasons at Olifants Drift, South-east Botswana // Journal of Arid Environments. Vol.40. P.255-268.

Moreno E. \& Espeso G. 2008. Cuviers's gazelle, Gazella cuvieri. International Studbook. Managing and Husbandry Guidelines. Ayuntamiento de Roquetas de Mar, Almería. 140 p.

Mphinyane W.N., Tacheba G. \& Makore J. 2015. Seasonal diet preference of cattle, sheep and goats grazing on the communal grazing rangeland in the Central District of Botswana // African Journal of Agricultural Research. Vol.10. No.29. P.2791-2803.

Ngwa A.T., Pone D.K. \& Mafeni J.M. 2000. Feed selection and dietary preferences of forages by small ruminants grazing natural pasture in the Sahelian zone of Cameroon // Animal Feed Science and Technology. Vol.88. P.253-266.

Omphile U.J., Aganga A.A. \& Malamba B. 2005. Diet and forage preference of communally grazed range goats in an Acacia bush savannah in southeast Botswana // Journal of Biological Sciences. Vol.5. No.6. P.690-693.
O’Reagain P.J. \& Mentis M.T. 1989. Seasonal changes in the quality of diet selected by cattle grazing the Natal Sourveld // Journal of the Grassland Society of Southern Africa. Vol.5. P.48-51.

Pianka E.R. 1973. The structure of lizard communities // Annual Review of Ecology and Systematics. Vol.4. P.53-74.

Papachristou T.G. \& Nastis A.S. 1993. Diets of goats grazing oak shrublands of varying cover in northern Greece // Journal of Range Management. Vol.46. P.220-226.

Papachristou T.G., Dziba L.E. \& Provenza F.D. 2005. Foraging ecology of goats and sheep on wooded rangelands // Small Ruminant Research. Vol.59. No.2. P.141-156.

Papanastasis V.P. 1997. Livestock grazing in Mediterranean ecosystems: an historical and policy perspective // Papanastasis V.P. \& Peter D. (eds.). Ecological basis of livestock grazing in Mediterranean ecosystems, European commision science, research and development, Proceedings of the International Workshop. Thessaloniki, Greece. P.5-9.

Pfister J.A. \& Malechek J.C. 1986. The voluntary forage intake and nutrition of goats and sheep in the semi-arid tropics of northeastern Brazil // Journal of Animal Science. Vol.63. No.4. P.1078-1086.

Prins H.H.T. 1992. The pastoral road to extinction: competition between wildlife and traditional pastoralism in East Africa // Environmental Conservation. Vol.19. P.117-123.

Putman R.J., Culpin S. \& Thirgood S.J. 1993. Dietary differences between male and female fallow deer in sympatry and allopatry // Journal of Zoology. Vol.229. No.2. P.267-275.

Ramirez R.G., Rios E. \& Garza J. 1993. Preference indices for forage species grazed by Spanish goats on a semi-arid shrubland // Journal of Applied Animal Research. Vol.3. No.1. P.55-66.

Schoener T.W. 1971. Theory of feeding strategies // Annual Review of Ecology and Systematics. Vol.2. No.1. P.369-404.

Schoener T.W. 1983. Field experiments on interspecific competition // The American Naturalist. Vol.122. P.240-285.

Schwartz C.C. \& Ellis J.E. 1981. Feeding ecology and niche separation in some native and domestic ungulates on the shortgrass prairie // Journal of Applied Ecology. Vol.18. No.2. P.343-353.

Seligman N.G. \& Perevolotsky A. 1994. Has intensive grazing by domestic livestock degraded Mediterranean Basin rangelands? // Arianoutsou M. \& Groves R.H. (eds.). Plant-animal Interactions in Mediterranean-type Ecosystems. Springer. P.93-103.

Sellami M. 1999. La Gazelle de Cuvier Gazella cuvieri (Ogilby, 1841) en Algérie. Statut et premiers éléments d'écologie, données sur le régime alimentaire dans la réserve naturelle de Mergueb (M'Sila) // Doct. Etat en Science Agronomique, Institut National Agronomique Alger, Algérie. 124 p.

Shipley L.A. 1999. Grazers and browsers: how digestive morphology affects diet selection // Launchbaugh K.L., Sanders K.D. \& Mosley J.C. (eds.). Grazing behavior of livestock and wildlife. Idaho Forest, Wildlife \& Range Experiment Station Bulletin. No.70. Moscow, Idaho: University of Idaho. P.20-27. 
Shrestha R., Wegge P. \& Koirala R.A. 2005. Summer diets of wild and domestic ungulates in Nepal Himalaya // Journal of Zoology. Vol.266. P.111-119.

Sih A. \& Christensen B. 2001. Optimal diet theory: When does it work, and when and why does it fail? // Animal Behaviour. Vol.61. No.2. P.379-390.

Soder J.K., Gregorini P., Scaglia G. \& Rook A.J. 2009. Dietary selection by domestic grazing ruminants in temperate pastures: current state of knowledge, methodologies and future direction // Rangeland Ecology \& Management. Vol.62. No.5. P.389-398.

Sparks D.R. \& Malechek J.C. 1968. Estimating percentage dry weights in diets using a microscope technique // Journal of Range Management. Vol.21. No.4. P.264-265.

Squires V.R. 1982. Competitive interactions in the dietary preference of kangaroos and sheep, cattle and goats in inland Australia // Journal of Arid Environments. Vol.5. P.337-345.

Stelfox B. \& Hudson R.J. 1986. Body condition of male Thomson's and Grant's gazelles in relation to season and resource use // African Journal of Ecology. Vol.24. No.2. P.111-120.

Stewart D.R.M., Stewart J., 1971. Comparative food preferences of five East African ungulates at different seasons // Watt E. \& Duffey A.S. (eds.). The Scientific Management of Animal and Plant Communities for Conservation. Oxford: Blackwell Science Publishing. P.351-366.

Stewart K.M., Bowyer R.T., Kie J.G., Cimon N.J. \& Johnson B.K. 2002. Temporospatial distributions of elk, mule deer, and cattle: resource partitioning and competitive displacement // Journal of Mammalogy. Vol.83. No.1. P.229-244.

Syed Z. \& Khan M.S. 2017. Livestock and wild herbivores in the western Himalaya: competition or co-existence? // Journal of Threatened Taxa. Vol.9. No.4. P.10084-10088.

Talbi K. 1989. Etude éco-éthologique de la Gazelle du Cuvier (Gazella cuvieri Ogilby, 1841) dans la zone de Djebel El Achch. Wilaya de Saïda. Thèse Magistère, Institut National Agronomique Alger, Algérie. 145 p.

Talbot L.M. \& Talbot M.H. 1962. Food preferences of some East African wild ungulates // East African Agricultural and Forestry Journal. Vol.27. No.3. P.131-138.
Thirwood J.V. 1981. Man and the Mediterranean Forest. New York: Academic Press. 194 p.

Van Dyne G.M. \& Heady H.F. 1965. Dietary chemical composition of cattle and sheep grazing in common on dry annual range // Journal of Range Management. Vol.18. P.78-86.

Vavra M. \& Sheehy D.P. 1996. Improving elk habitat characteristics with livestock grazing // Rangelands. Vol.18. P.182-185.

Voeten M.M. 1999. Living with wildlife: coexistence of wildlife and livestock in an East African savanna system // $\mathrm{PhD}$ Thesis, Wageningen University, Wageningen, the Netherlands. $168 \mathrm{p}$.

Wang L., Wang D., Liu J., Huang Y. \& Hodgkinson K.C. 2011. Diet selection variation of a large herbivore in a feeding experiment with increasing species numbers and different plant functional group combinations // Acta Oecologica. Vol.37. No.3. P.263-268.

Ward A.L. 1970. Stomach content and fecal analysis: methods of forage identification // Range and Wildlife Habitat Evaluation: A Research Symposium, D.C. Washington, U.S. Department of Agriculture, Forest Service, Miscellaneous Publication. No.1147. P.146-158.

Wiens J.A. 1977. On competition and variable environments // American Scientist. Vol.65. P.590-597.

Xu W., Xia C., Yang W., Blank D.A., Qiao J. \& Liu W. 2012. Seasonal diet of khulan (Equidae) in Northern Xinjiang, China // Italian Journal of Zoology. Vol.79. No.1. P.92-99.

Yahi N., Benhouhou S., Véla E., De Belair G. \& Gharzouli R. 2011. Algeria // Radford E.A., Catullo G. \& de Montmollin B. (eds.). Important Plant Areas of the south and east Mediterranean region: Priority Sites for Conservation. Malaga: IUCN. P.27-30.

Zaime A. \& Gautier J.Y. 1989. Comparaison des régimes alimentaires de trois espèces sympatriques de Gerbillidae en milieu saharien au Maroc // Revue d'Ecologie (Terre Vie). Vol.44. No.2. P.153-163. 